\title{
PPAR agonists as effective adjuvants for COVID-19 vaccines, by modifying immunogenetics: a review of literature
}

Antoine Fakhry AbdelMassih ${ }^{1,2^{*}}$ (D), Rahma Menshawey ${ }^{3}$, Jumana H. Ismail ${ }^{4}$, Reem J. Husseiny ${ }^{3}$, Yousef M. Husseiny ${ }^{5}$, Shenoda Yacoub ${ }^{3}$, Aya Kamel ${ }^{3}$, Rafeef Hozaien ${ }^{3}$, Elaria Yacoub ${ }^{3}$, Esraa Menshawey ${ }^{3}$, Abanoub Abdelmalek ${ }^{3}$, Ahmed Abouelazaem ${ }^{3}$, Ahmed Elhatw ${ }^{3}$, Ahmed Aboelmaaty ${ }^{3}$, Alaaelrahman Shahib ${ }^{3}$, Amany Mansour $^{3}$, Aya Kamal ${ }^{3}$, Basant Mohamed ${ }^{3}$, Bemen Atif ${ }^{3}$, Beshoy Ghabreal ${ }^{3}$, Catherine Abdelmalak ${ }^{3}$, David Ibrahim³, Ebtesam Elsaify ${ }^{3}$, Farah Magdy ${ }^{3}$, Farid G. Hanna ${ }^{3}$, Hadeer Hafez ${ }^{3}$, Hafsa Dahir ${ }^{3}$, Kerlos Merhom ${ }^{3}$, Maram Ahmed ${ }^{3}$, Mariam Bishara ${ }^{3}$, Mina Tawfik ${ }^{3}$, Mina Youssef ${ }^{6}$, Mohamed El Sharnouby $^{3}$, Mourad Hamouda $^{3}$, Musheera Ammar $^{3}$, Nada Ali ${ }^{3}$, Nada Daniel ${ }^{7}$, Nadine El-Husseiny ${ }^{8,9}$, Noha Abdelraouf ${ }^{3}$, Nuran K. Abdelhameed ${ }^{3}$, Radwa Ahmed ${ }^{3}$, Radwa Othman ${ }^{3}$, Rahma Mohamadein ${ }^{3}$, Rana Allam ${ }^{3}$, Rana Elgendy ${ }^{3}$, Rana Shebl ${ }^{3}$, Saged Elsherbiney ${ }^{3}$, Sarah Fouad ${ }^{3}$, Sara Emel ${ }^{3}$, Sara Owais ${ }^{3}$, Sarah Hetta ${ }^{3}$, Samah El-Saman ${ }^{3}$, Shaimaa Abdelalim ${ }^{7}$, Sherin Galal ${ }^{3}$, Yara Asar ${ }^{3}$, Yara Osman ${ }^{7}$, Yasmeen Khalaf ${ }^{3}$, Youstina Aziz ${ }^{10}$, Yousra Khafagy ${ }^{3}$, Nervana Gamal ${ }^{3}$ and Biagio Castaldi ${ }^{11}$

\begin{abstract}
Background: Several coronavirus vaccine have been fast-tracked to halt the pandemic, the usage of immune adjuvants that can boost immunological memory has come up to the surface. This is particularly of importance in view of the rates of failure of seroconversion and re-infection after COVID-19 infection, which could make the vaccine role and response debatable. Peroxisome proliferator-activated receptors (PPARs) have an established immune-modulatory role, but their effects as adjuvants to vaccination have not been explored to date.

Main body of the abstract: It is increasingly recognized that PPAR agonists can upregulate the levels of antiapoptotic factors such as MCL-1. Such effect can improve the results of vaccination by enhancing the longevity of long-lived plasma cells (LLPCS). The interaction between PPAR agonists and the immune system does not halt here, as T cell memory is also stimulated through enhanced T regulatory cells, antagonizing PD-L1 and switching the metabolism of $T$ cells to fatty acid oxidation, which has a remarkable effect on the persistence of $T$ memory cells. What is even of a more significant value is the effect of PPAR gamma on ensuring a profound secretion of antibodies upon re-exposure to the offending antigen through upregulating lipoxin B4, therefore potentially assisting the vaccine response and deterring re-infection.
\end{abstract}

\footnotetext{
* Correspondence: antoine.abdelmassih@kasralainy.edu.eg

'Pediatric Cardiology Unit, Pediatrics' Department, Cairo University Children

Hospital, Faculty of Medicine, Cairo University, Kasr Al Ainy Street, Cairo

12411, Egypt

${ }^{2}$ Pediatric Cardio-Oncology Department, Children Cancer Hospital of Egypt

(57357), Cairo, Egypt

Full list of author information is available at the end of the article
}

\section{Springer Open}

(c) The Author(s). 2021 Open Access This article is licensed under a Creative Commons Attribution 4.0 International License, which permits use, sharing, adaptation, distribution and reproduction in any medium or format, as long as you give appropriate credit to the original author(s) and the source, provide a link to the Creative Commons licence, and indicate if changes were made. The images or other third party material in this article are included in the article's Creative Commons licence, unless indicated otherwise in a credit line to the material. If material is not included in the article's Creative Commons licence and your intended use is not permitted by statutory regulation or exceeds the permitted use, you will need to obtain permission directly from the copyright holder. To view a copy of this licence, visit http://creativecommons.org/licenses/by/4.0/. 
Short conclusion: In view of the above, we suggest the use of PPAR as adjuvants to vaccines in general especially the emerging COVID-19 vaccine due to their role in enhancing immunologic memory through DNA-dependent mechanisms.

Keywords: COVID-19 vaccine, PPAR, Immunologic memory

\section{Background}

The ongoing humanitarian crisis caused by COVID-19 which started in Wuhan has brought the world to a standstill $[1,2]$. As of yet, COVID-19 cases have surpassed 160 million individuals, causing more than 3 million deaths, and counting [3].

Several widely anticipated vaccines targeting COVID are underway, the main constitutions of which are either recombinant viral-vectored, mRNA-based, or protein subunit vaccines. SARS-COV-2 has various structural proteins. Its $\mathrm{S}$ protein, in particular, generates antibodies that were found to be neutralizing to the virus. Consequently, all COVID-19 vaccines incorporate at least a portion of $S$ protein [4]. $S$ protein subunit vaccines mainly work by inducing $\mathrm{CD} 4+\mathrm{TH}$ cell and antibody response; however, they had a weaker $\mathrm{CD} 8+\mathrm{T}$ cell response [5].

They were found to require adjuvant and repeated doses to effectively stimulate high titers of neutralizing antibodies to minimize the possibility of antibodydependent enhancement of disease (ADE) [6]. mRNAbased vaccines, complexed with lipid nanoparticle carriers, induce strong antibody response targeting $\mathrm{S}$ proteins as well as $\mathrm{CD} 4+$ and $\mathrm{CD} 8+\mathrm{T}$ cell response. However, the magnitude and duration of these immune responses are still in question. Observing the development of B or $\mathrm{T}$ cell memory using next-generation sequencing, as well as the rate of seroconversion and lastly the re-infection rates and severity, can provide useful insights on the extent of immunologic memory developed after COVID-19. These insights can give us an idea about the potential longevity of protection provided by the vaccines under-development and how to improve it.

The SARS-CoV infection is thought to disrupt multiple aspects of immunity. In particular, Liao and colleagues emphasized the lack of evidence for B cell memory generated in severe patients during the early recovery period. This might potentially render them susceptible to COVID-19 re-infection and decreases the likelihood of developing long-lasting immunologic memory [7].

Indeed, re-infection from COVID-19 has been a disappointing matter that has turned around the approach of post-infection cases' follow-up. A study reported that $11 \%$ of recovered COVID-19 Chinese patients were re-infected although they were asymptomatic [8]. Moreover, surveillance after patients discharged in Guangdong, China, reported that $9.5 \%$ got re-infected [9]. A systematic review conducted by Gidari et al. with a total of 82 papers thoroughly searched concluded that 1350 patients that were infected with COVID-19 had manifested with positive respiratory investigative criteria after recovery [10]. Another report by AbdelMassih and colleagues concluded that of the re-infected cases especially those who failed to seroconvert after the initial infection developed more severe manifestations in the re-infection episode.

Despite a promising recent report by Lumley et al. who showed that seroconversion conveys immunity and shields patients from severe re-infection, however, antibodies have been found to wain within 2 months after infection, suggesting shortened protection. Another challenge to long-lasting immunity from COVID-19 is the non-negligible percentage of patients who fail to seroconvert after initial infection, which is approximately $10-12 \%$ in most of the series exploring antibody status in affected patients [11].

Peroxisome proliferator-activated receptors (PPARs) are members of the nuclear hormone receptor superfamily of which there are three isoforms: PPAR $\alpha, \operatorname{PPAR} \beta / \delta$, and PPAR $\gamma$. It increasingly recognized that members of the nuclear-receptor superfamily have significant regulatory effects on inflammatory processes [12] and thus PPAR agonists and antagonists have been implemented in multiple clinical trials for their immunomodulatory role. Distinctively, a study highlighted using a mouse model that PPARY is crucial for optimal humoral immune responses. The study showed that mice lacking PPARy expression in B cells had decreased proliferation and IgG production in vitro, as well as low levels of circulating antigen-specific antibodies during a primary response. This was also reflected in the immune memory response where PPAR $\gamma$-deficient mice had a form of impairment of said immunity with low numbers of antigen-experienced antibody-secreting cells. The results showed the importance of PPAR $\gamma$ expression in B cells during both the primary and secondary immune response [13]. Another study showcased that physiological doses of PPAR $\gamma$ ligands alone or in combination with other ligands accelerate the differentiation of B cells into plasma cells resulting in the heightened synthesis of immunoglobulins. The literature supports that the PPAR $\gamma$ activation pathway can be utilized to boost the humoral immune response [13]. Despite the increasing body of 
evidence that PPAR can have an immunomodulatory role in the context of COVID-19 infection, its role in improving vaccine responses has not been explored to date.

These receptors all share in common a unified structure as follows: N-terminal ligand-independent transactivation domain, a DNA binding domain, and a C-terminal ligand-binding domain and ligand-dependent activation domain. Having both a DNA binding domain and a ligand-binding domain that can be stimulated by different types of agonists-drugs has made these molecules an important tool for the modification of DNA transcription in various cells to modify cell behavior towards a required therapeutic target. As mentioned earlier, one of the most important therapeutic effects that are being a point of focus in the recent years is their immunomodulatory role through interaction with nuclear DNA of various types of immune cells. However, despite thorough investigations in this context, none has focused on their role in improving vaccination responses, the socalled, vaccination adjuvant role. Several vaccination adjuvants have been tailored over years to be coupled to vaccines to enhance immune responses and seroconversion after vaccination [14]. The major adjuvant established for most of the available vaccines is aluminum. Its mode of action was based upon prolonging the interaction between the antigen and the immune system by delaying the degradation of the antigen provided by vaccination. This old strategy is being slowly replaced by a newer strategy, which is the stimulation and modification of immune cells' behavior through stimulation of Toll-like receptors, crucial receptor of the innate and adaptive immune system to enhance their reactivity to the administered antigen. Most of the investigated molecules are either portions of double-stranded DNA (ds DNA) or small ligand proteins [15].

Immunological memory is the cornerstone of vaccine effectiveness; therefore, the competent regulation of memory cells' expression will highly guarantee promising vaccine outcomes. With anticipation growing, for an answer for this unprecedented global pandemic, any potential vaccine alone might not be the end all be all, potentially needing to be fortified to ensure its potency. The augmented proliferation of memory $\mathrm{B}$ cells is proven to be in a direct correlation with the use of PPAR $\gamma$ ligands. Garcia-Bates et al. [14] have also demonstrated the influence of PPARy ligands' downregulation on $\mathrm{T}$ cell proliferation, which will furthermore boost the expression of IFN- $\gamma$ and IL-12. The cytokines released in response to $\mathrm{T}$ cell functioning synergistically enhance the roles of $\mathrm{B}$ cells in combating current and foreseen re-infection.

Given this new strategy, and the potential of PPARs to modify and enhance the reactivity of immune cells through epigenetic and DNA-linked mechanisms, we hypothesize that PPARs can be proposed as potential and affordable adjuvants for vaccines. The aim of this work is to prove such hypothesis through a thorough review of the available literature of the effect of PPARs on $\mathrm{B}$ and $\mathrm{T}$ cell memory.

\section{Main text \\ Prolonging B cell memory and improving secondary antibody response}

B cells are an essential component of humoral immunity [16]. Immature B cells that are exiting the bone marrow acquire immunoglobulin (Ig)D, cluster of differentiation (CD)21, and CD22 on their surface [17]. Following antigen exposure, most of the $\mathrm{B}$ cells outside the gutassociated lymphoid tissue (GALT) which reside in the spleen and lymph nodes develop immunologic memory through four steps:

(1) Respond to T cell-dependent foreign antigens, (2) proliferate, (3) differentiate into long-lived plasma/memory B cells (secrete abundant amounts of antibodies), or (4) enter into the germinal center (GC) [18-20]. Therefore, the optimal humoral response depends on the formation of antigen-specific titers that are produced by non-proliferating long-lived plasma cells (LLPC), which are located within the bone marrow. The hallmark of LLPC is longevity. Only recently, are we beginning to understand the functions and mechanisms of survival of these cells even after years of antigen exposure. It should be noted that LLPCs are not intrinsically long-lived and require continuous signaling from their LLPC niche in order to survive. We are exploring in this section the signals needed to maintain the survival of LLPCs and their relationship with the PPAR pathway [21].

\section{PPARY induced upregulation of anti-apoptotic factors}

Signals that are responsible for the upregulation of the anti-apoptotic factor Mcl-1, which is expressed on LLPC, are essential for LLPC survival [21].

BCL-2 family can be considered a tripartite apoptosis control system consisting of (1) a set of anti-apoptotic proteins and (2) two sets of pro-apoptotic proteins, both of which collaborate to determine the survival or death of the cell in different pathophysiological states: 1, 2, 3, and 4. BCL-2, BCL-XL, BCL-W, MCL-1, and A1/BFL-1 are five known anti-apoptotic members that are similar in four BCL-2 homologies (BH) domains [22].

$\mathrm{Wu}$ and colleagues succeeded in demonstrating the ability of Rosiglitazone, a PPAR $\gamma$ agonist, in increasing cell viability and stability of the mitochondrial membrane. This effect was mediated through upregulation of the anti-apoptotic members of the BCL-2 family [23]. 


\section{Metabolic fitness}

Metabolic fitness is another essential component of LLPC longevity, which facilitates the diversion of glucose in order to generate pyruvate in a state of stress to facilitate long-term survival [21].

PPAR induces and orchestrates a switch from glucose to fatty acid utilization for energy production in hepatocytes. Notably, there is simultaneous activation of FAO by PPAR $\alpha$ and inhibition of glycolysis. PPAR $\alpha$ activation reduces PK expression and induces pyruvate dehydrogenase lipoamide kinase. This effect will generate pyruvate and will prevent pyruvate internalization into the mitochondria, thus providing a metabolic niche for the long-term survival of LLPCs [24].

\section{Cellular partners of LLPCs}

The LLPC niche is the third major component of LLPC survival. It is composed of other cellular partners such as dendritic and $\mathrm{T}$ regulatory cells, which promote survival signaling by:

(1) The expression of ligands such as CD80/CD86 for CD28 and

(2) Produce soluble and stromal factors, which contribute to LLPC longevity [21]

Wang and associates were able to study the effect of PPAR $\gamma$ on Treg cells in a murine model of allergic rhinitis and reported that pioglitazone significantly increased the expression of Foxp3 mRNA as well as the population of Tregs [25].

In a study assessing the effects of PPAR $\gamma$ agonists on dendritic cells, Szatmari et al. found that PPAR $\gamma$ orchestrates a transcriptional response, which results in the development of a DC subtype with (1) increased internalizing capacity, (2) efficient lipid presentation, and (3) an augmented potential to activate iNKT cells and LLPCs [26].

We can conclude from the above that both PPAR $\gamma$ and $\alpha$ can increase the longevity of LLPCs and therefore improve the results of vaccination.

\section{Improving secondary antibody response through PPAR}

Another mechanism that can explain inter-personal variability to vaccines is the ability of LLPCs to produce an efficient secondary antibody response. This potential has been of special interest to Kim and colleagues. The latter analyzed the molecular basis of such potential and demonstrated that secondary antibody response is mediated by "proresolving mediators." This family comprises a large group of endogenously produced lipids, of which lipoxin B4 particularly operates to stimulate memory B cells to secrete antibodies upon re-exposure to the offending antigen [27, 28].
Lipoxin B4 seems to act through several intertwined molecular mechanisms, namely retinoic acid pathway, COX-2, and Blimp-1. All of which including lipoxin B4 were proved to be upregulated by PPARY.

\section{PPARY and evidence from vaccinations}

A vaccine can generate specific long-lived plasma cells, memory B cells, and serum antibodies [29]. Although it is unclear as to how these elements are preserved over time, it should be noted that when judging the efficacy of a vaccine, we only measure serum antibodies, which are just one of the three components of immunological memory [29].

After primary immunization, long-lived plasma cells produce the remaining specific antibodies in the body, whereas boosters increase as a result of memory B cells [29]. There are two hypotheses regarding "serological memory"; the first suggests that long-lived plasma cells are sufficient to maintain memory, whereas the second theory suggests that serological memory is replenished by continuous stimulation of memory B cells [29]. Memory B cells, responsible for fast recall responses, have a limited life span and therefore suggest the need for cyclic re-stimulation to maintain memory against a particular pathogen [29].

Kye et al. [30], when assessing the effect of PPAR $\gamma$ on intranasal vaccination of Streptococcus pneumoniae in mice, found that serum antibody levels of mice injected with PPAR $\gamma$ antagonist (GW9662) before vaccination was markedly reduced in comparison to the mice that received the vaccination directly. This indicates that PPAR $\gamma$ is one of the most highly upregulated genes that induce long-term immunity via B cells [30]. After injection of a lethal dose of S. pneumoniae 12 weeks after vaccination, there was $100 \%$ survival rate, thus confirming the use of PPARY and its agonists as a benefit in the setting of vaccination [30].

This data would further prove our hypothesis that the use of PPAR $\gamma$ agonists would promote the proliferation and differentiation of $\mathrm{B}$ cells in a synergistic manner, which would enhance the memory of B cells. In the setting of COVID-19 vaccination, the use of these substances will help to maintain serological memory against SARS-COV-2 viral particles may be through a "booster effect," which has yet to be proven.

\section{Prolonging T cell memory with PPAR}

PPAR- $\gamma$ was originally identified as the molecular target for the thiazolidinedione (TZD) class of antidiabetic drugs [31]. Subsequent medical research indicated that PPAR- $\gamma$ is highly expressed in secondary lymphoid organs and cells of the immune system and it has also been documented that PPAR- $\gamma$ loss leads to enhanced proliferation of lymphocytes, which reflects the 
important role PPAR- $\gamma$ plays in regulating immune responses [32].

Given the high impact on the inflammatory process of PPAR- $\gamma$ activation, the use of PPAR- $\gamma$ agonists has been suggested as one of the potential therapeutic compounds capable of treating cytokine storms that usually take place during severe viral influenza. For example, in 2009, Aldridge et al. showed that administration of pioglitazone to mice increased the rate of CD8 $+\mathrm{T}$ cells in infected lungs leading to decreased morbidity and mortality due to the influenza virus A [33]. A second study was carried out in 2010 which endorsed the therapeutic use of thiazolidinedione, demonstrating the effectiveness of rosiglitazone and pioglitazone in reducing the cytokine storm-induced inflammatory mechanism in the H1N1 influenza A virus in the mouse model [34]. One of the sites where PPAR is expressed is the lungs [35]. Studies have shown that mice deficient in PPAR $\alpha$ have an increased inflammatory pulmonary response to lipopolysaccharide-induced inflammation [36]. As a result, the decrease in PPAR $\alpha$ due to COVID-19 can potentially be the main factor in the cause of pulmonary inflammation and be involved in the pathogenesis of acute lung injury [35]. However, the role of PPAR in improving $\mathrm{B}$ or $\mathrm{T}$ cell-mediated immunologic memory, and its subsequent potential to improve vaccine responses, was not explored to date.

\section{Stimulation of $T$ cell memory through enhancing $T$ regulatory cells.}

Recent evidence shows that PPAR- $\gamma$ plays an important role in regulating the plasticity of Th17 to iTreg multiple functional phenotypes. Additionally, PPARy is involved in $\mathrm{T}$ cell differentiation to Th17 or iTreg cells by upregulation of Th17 receptors and downregulation of iTreg cell receptors (FOXP3) in mice. Computational results, adoptive transfer studies, and co-transfer studies in mice supported the initial prediction that PPARy activation increases iTreg cell differentiation.

Moreover, there were more short-lived effector CD8+ $\mathrm{T}$ cells during the peak of the immune response in the spleens of mice lacking Treg, but the memory CD8+ T cell response was impaired. Therefore, Treg-dependent production of TGF- $\beta$ led to an increased expression of CD103 on CD8+ T cells, providing a large pool of resident memory $\mathrm{T}$ cells to be maintained in the brain postinfection [37].

\section{Upregulation of $\gamma \delta T C R$ and its role in improving $T$ cell survival}

$\mathrm{T}$ cell diversity is an essential aspect of an effective immune system. Two entities of $\mathrm{T}$ cells have been identified, namely $\gamma \delta$ and $\alpha \beta \mathrm{T}$ cells. Studies on murine models conclude that subpopulations of $\gamma \delta \mathrm{T}$ cells can develop long-lasting memory with protective properties in comparison with the conventional $\alpha \beta$ T cells [38]. Study shows TCR $\gamma \delta$ is relatively increased by around 5 folds via PPAR $\beta$ stimulation [39].

\section{Switching the metabolism of $T$ cells to fatty acid oxidation}

We have come to the understanding that PPARs' physiological function is through their action as transcription factors, controlling the expression of specific target genes. PPAR alpha modulates the transcription of genes involved in beta-oxidative degradation of fatty acids while PPAR gamma acts on glucose homeostasis by helping the differentiation of immature adipocytes to mature adipocytes [40]. They are also related to the nuclear hormone receptor superfamily and control multiple physiological functions such as development, energy metabolism, cellular differentiation, and inflammation.

Lipid metabolism has a significant effect on $\mathrm{T}$ cells' fate and function [41], and generation of CD8+ memory $\mathrm{T}$ cells requires metabolic reprogramming that is characterized by enhanced mitochondrial fatty acid oxidation (FAO) [42]. Le Menn et al. declare that CD8+ memory $\mathrm{T}$ cells were found to heavily rely on FAO to meet their metabolic demands, and therefore, the expression of carnitine palmitoyl-transferase 1a (CPT1a), which is the limiting enzyme of FAO, is proven to shift the differentiation of $\mathrm{T}$ cells towards the CD8+ subset [43]. Memory $\mathrm{CD}^{+}$and Treg cells, which rely on FAO [44], utilize FAO to support their development and long-term survival without the need to rely on extracellular fatty acids [45]. Previous studies demonstrating the association between FAO and the enhanced survival of CD8+ memory $\mathrm{T}$ cells have helped establish the link between FAO and cellular longevity in the immune system [42].

Moreover, FA derived from lipolysis can fuel oxidative phosphorylation (OXPHOS), and lipolysis is also required for the production of lipid signaling molecules, such as lipid ligands, to activate the peroxisome proliferator-activated receptor (PPAR) pathway [42]. Furthermore, fatty acid binding proteins (FABP) 4 and 5 control lipid uptake and metabolism and thus act as a regulator of tissue-resident memory $\mathrm{CD} 8+\mathrm{T}$ cell function in the lung [46], and PPAR- $\gamma$ regulates their expression [47].

Mothe-Satney et al. conducted a study that proved that stimulation of the peroxisome proliferator-activated receptor $\beta$ (PPAR $\beta)$ increases fatty acid oxidation in $\mathrm{T}$ cells. It showed that activation of PPAR- $\beta$ supports fatty acid oxidation instead of aerobic glycolysis and this favors the increase in the long-surviving memory $\mathrm{T}$ cells. Moreover, it showed that PPAR- $\beta$ controls the expression of genes related to fatty acid oxidation such as acetyl-CoA acyltransferase 2 (Acaa2), very long-chain acyl-CoA dehydrogenase (Acadvl), and Cpt1a [39]. 
PPAR- $\gamma$ is essential for the development of preadipocytes to adipocytes [48]; although it inhibits the generation of effector cells with Th17 properties, it increases the generation of the memory cells as it depends on fatty acid metabolism rather than glycolysis. In addition, PPAR- $\gamma$ directly binds on DNA and controls the expression of genes related to fatty acid uptake and oxidation [48], whereas PPAR- $\alpha$ regulates genes involved in oxidative degradation of fatty acids. Another study suggested that FAO was promoted by using PPAR- $\alpha$ agonist, fenofibrate, which improved CD8 ${ }^{+}$TIL's ability and synergized with PD-1 blockade. This effect could have been linked with enhanced oxidative phosphorylation, and mitogenic ROS production from mitochondria is supported by similar studies in which treatment with PPAR activator bezafibrate combined with PD-1 blockade, but not alone, led to $\mathrm{CD}^{+} \mathrm{T}$ cell activation through mitochondrial expansion $[49,50]$. Therefore, having an increased mitochondrial mass and enhanced sparse respiratory capacity allows memory $\mathrm{T}$ cells to rapidly respond to an antigen-mediated rechallenge [45].

\section{Antagonizing PD- $L$ which prevents $T$ memory cells from developing}

PPAR-a agonist, through fatty acid catabolism, improves $\mathrm{T}$ cell lymphocyte functions and enhances the therapeutic effect of PD-1 blockade in melanoma. FAs are converted to acetyl-CoA that acetylate key enzymes within the TCA cycle, which increases GAPDH's enzymatic activity and reduces its binding to the 3'UTR region of IFN-g mRNA, thus enhancing IFN-y production [51] and $\mathrm{T}$ cell effector functions.

CD8+ T lymphocyte exhaustion and loss of effector functions are signaled by high expression of PD-1 as it facilitates the CD8+ TILs' metabolic switch within a Glc-poor tumor microenvironment (TME) [52]. Therefore, the efficacy of cell therapy in patients with cancers characterized by low glucose content can be enhanced by PPAR-a agonist's metabolic reprogramming of CD8+ $\mathrm{T}$ cells [49].

Furthermore, dendritic cells are essential for CD8+T cell activation, and during this process, PD-L and CD80 are expressed on their surface. Through a programming mechanism during this activation phase, differentiation of the effector and memory CD8+ T cells occurs, and during this programming, external stimuli as TCR signaling, co-stimulatory signaling, and cytokine signaling affect naïve $\mathrm{CD} 8+\mathrm{T}$ cells [53]. In order to modulate the differentiation of effector and memory CD8 $+\mathrm{T}$ cells, PD-L1 signaling is integrated during $\mathrm{CD} 8+\mathrm{T}$ cell activation. An investigation showed the effect of PD-L signaling during activation on the resulting antigen-

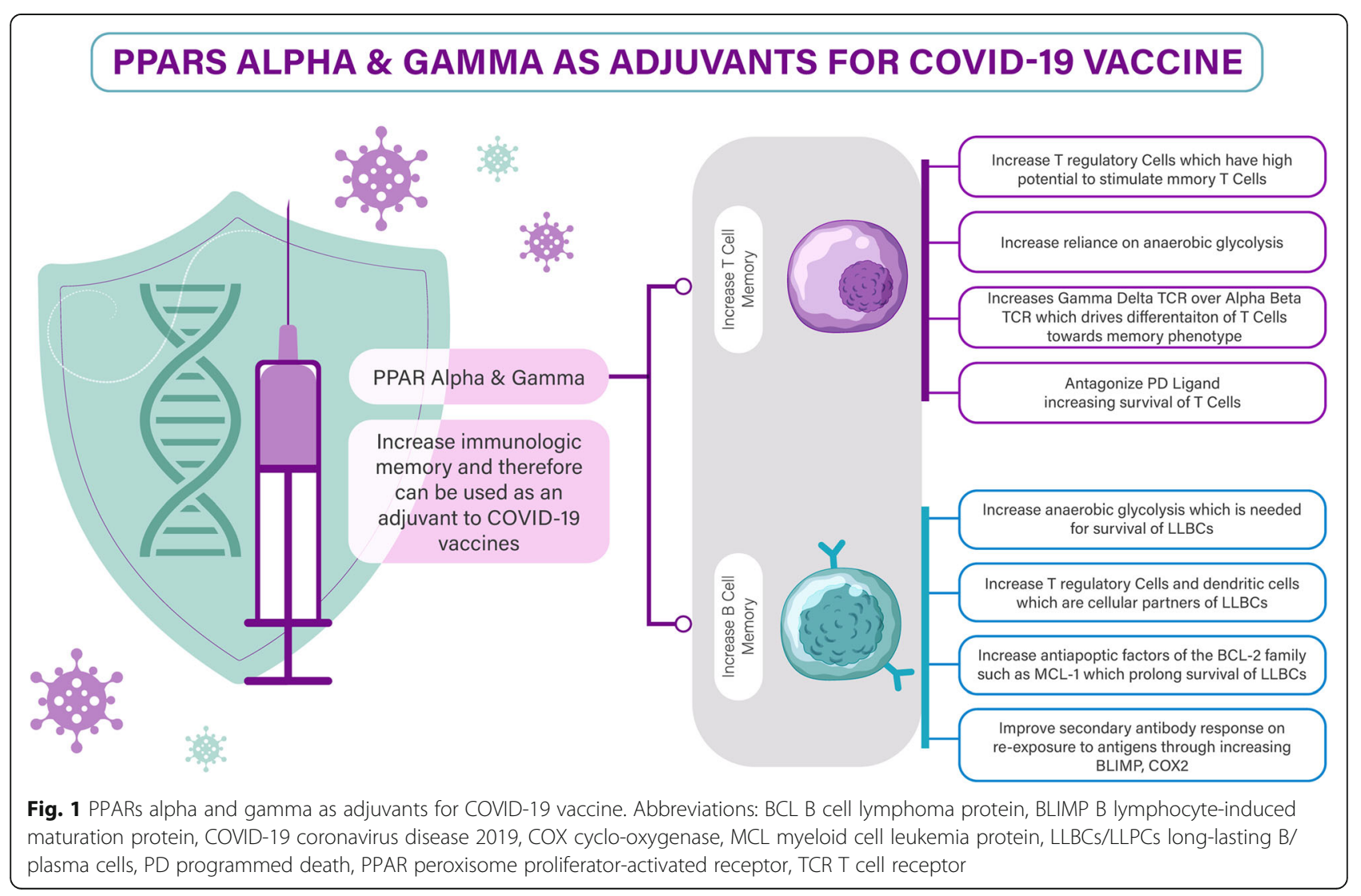


specific CD8+ T cell memory population. An experiment was performed where PD-L1 blocking antibodies were given to mice before and after HSV-1 infection and mice were subjected to the virus later. The CD8+ T cell responses were evaluated after re-infection. The memory response in mice that activated the anti-HSV-1 CD8+ memory $\mathrm{T}$ cells in the absence of PD-L1 showed increased antigen-specific secretion of IFN-gamma and granzyme B [54, 55]. Figure 1 summarizes the mechanisms by which PPARs (alpha nad gamma) can act as adjuvants to the immune respone genertaed by curretly available COVID-19 vaccines.

\section{Conclusion}

As vaccine effectiveness depends on immunological memory, this research throws light on how PPAR can be used to enhance both $\mathrm{B}$ memory and $\mathrm{T}$ memory cells through various mechanisms. Studies have shown that PPAR will improve the secondary antibody response of $B$ cells through lipoxin B4, retinoic acid, COX-2, and Blimp-1; increase the lifespan of LLPC; and stimulate the upregulation of anti-apoptotic factors of the BCL-2 family. Moreover, studies have also shown that PPAR has an increased FAO on T cells stimulating the production of CD $8+$ memory T cells, an increase in $\mathrm{TCR} \gamma \delta$ by 5 folds approximately and antagonizing of PD-L, which prevents $\mathrm{T}$ memory cells from developing. Thus, we believe PPAR agonists would ensure a worthwhile vaccine response and prevent re-infection. We thereby urge working groups across the world who are testing the different types of COVID-19 vaccines to test the validity of this hypothesis through prospective trials.

\footnotetext{
Abbreviations

BCL: B-cell lymphoma; BLIMP: B lymphocyte-induced maturation protein; CD: Cluster of differentiation; COVID-19: Coronavirus disease 2019;

COX: Cyclo-oxygenase; DNA: Deoxyribonucleic acid; FABP: Fatty acid binding protein; FAO: Fatty acid oxidation; FOXP3: Forkhead box P3; Glc: Glucose; IFN: Interferon; IL: Interleukin; LLPC: Long-lasting plasma cell; MCL: Myeloid cell leukemia; NK: Natural killer; PD-L1 : Programmed death ligand 1; PK: Pyruvate kinase; PPAR: Peroxisome proliferator-activated receptor; RNA: Ribonucleic acid; SARS-COV-2: Severe acute respiratory distress syndrome coronavirus 2; T reg: T regulatory; TCA: Tricarboxylic acid cycle; TCR: T cell receptor; TGF: Transforming growth factor; TH: T helper; TIL: Tumor infiltrated lymphocyte; Treg: T regulatory cell; UTR: Untranslated region
}

\section{Acknowledgements}

To our families who are bearing the weight of our sacrifice of time to our patients. If our families were not understanding to the depth of our struggle, we would have never been able to keep the same level of dedication to our patients. To our students that we involve in each step of our researches to make them flourish in this field and take the lead the soonest the possible. We want to thank every front-liner in all medical facilities around the world they have helped many of us to preserve their loved ones, sometimes at the expense of their own lives. As a first auhor, I wanted to thank the wonderful families of my students who co-authored with me, this work as well as many of my previous works. Finally, I wanted to thank my very dear work partner Habiba-Allah Ismail, who was not able to partner in this work, her presence and perseverance, were greatly needed and missed during the writing of this manuscript.

\section{Authors' contributions}

$\mathrm{AA}, \mathrm{EY}, \mathrm{RH}$, and $\mathrm{RM}$ contributed to the conception and design of the work. $A A, R M, J l, R H, Y H, S Y, A K, R H(2), E Y, E M, A A(2), A A(3), A E, A A(4), A S, A M$, $A K(2), B M, B A, B G, C A, D I, E E, F M, F H, H H, H D, K M, M A, M B, M T, M Y, M E, M H$, $M A(2), N A, N D, N E, N A(2), N K A, R A, R O, R M(2), R A(2), R E, R S, S E(2), S F, S E(3)$, SO, SH, SE(4), SA, SG, YA, YO, YK, YA(2), YK(2), NG, and BC contributed significantly to the acquisition of the data. AA, RM, Jl, RH, YH, SY, AK, RH(2), $E Y, E M, A A(2), A A(3), A E, A A(4), A S, A M, A K(2), B M, B A, B G, C A, D I, E E, F M, F H$, $H H, H D, K M, M A, M B, M T, M Y, M E, M H, M A(2), N A, N D, N E, N A(2), N K A, R A$, $\mathrm{RO}, \mathrm{RM}(2), \mathrm{RA}(2), \mathrm{RE}, \mathrm{RS}, \mathrm{SE}(2), \mathrm{SF}, \mathrm{SE}(3), \mathrm{SO}, \mathrm{SH}, \mathrm{SE}(4), \mathrm{SA}, \mathrm{SG}, \mathrm{YA}, \mathrm{YO}, \mathrm{YK}$, $Y A(2), Y K(2), N G$, and $B C$ contributed to the analysis and interpretation of the data. RM contributed to the drafting and revision of the manuscript. All authors have approved the submitted version. All authors have agreed both to be personally accountable for the author's own contributions and to ensure that questions related to the accuracy or integrity of any part of the work, even ones in which the author was not personally involved, are appropriately investigated, resolved, and the resolution documented in the literature. NB: Due to identical initials of some authors, we specified the authors' initials in the list of emails.

\section{Funding}

This research received no specific grant from any funding agency, commercial, or not-for-profit sectors.

Availability of data and materials

Not applicable.

\section{Declarations}

Ethics approval and consent to participate

Not applicable.

Consent for publication

Not applicable.

\section{Competing interests}

The authors declare that they have no competing interests.

\section{Author details}

${ }^{1}$ Pediatric Cardiology Unit, Pediatrics' Department, Cairo University Children Hospital, Faculty of Medicine, Cairo University, Kasr Al Ainy Street, Cairo 12411, Egypt. ${ }^{2}$ Pediatric Cardio-Oncology Department, Children Cancer Hospital of Egypt (57357), Cairo, Egypt. ${ }^{3}$ Research Accessibility Team, Student and Internship research program, Faculty of Medicine, Cairo University, Giza, Egypt. ${ }^{4}$ Pulmonology Department, Faculty of Medicine, Cairo University, Giza, Egypt. ${ }^{5}$ Research Accessibility Team, Student and Internship research program, Faculty of Medicine, New Giza University, 6th of October City, Egypt. ${ }^{6}$ University at Buffalo School of Medicine and Biomedical, Buffalo, USA. ${ }^{7}$ Research Accessibility Team, Student and Internship research program, Faculty of Medicine, Ain Shams University, Cairo, Egypt. ${ }^{8}$ Faculty of Dentistry, Cairo University, Giza, Egypt. ${ }^{9}$ Pixagon graphic design Agency, Cairo, Egypt.

${ }^{10}$ Research Accessibility Team, Student and Internship research program,

Faculty of Medicine, 6th October University, 6th of October City, Egypt.

${ }^{11}$ Padova University, Padua, Italy.

Received: 12 March 2021 Accepted: 14 May 2021

Published online: 31 May 2021

\section{References}

1. Moon SS, Lee K, Park J, Yun S, Lee YS, Lee DS (2020) Clinical characteristics and mortality predictors of COVID-19 patients hospitalized at nationallydesignated treatment hospitals. J Korean Med Sci 35(36):e328. https://doi. org/10.3346/jkms.2020.35.e328

2. Hua J, Shaw R (2020) Corona virus (COVID-19) "infodemic" and emerging issues through a data lens: the case of China. Int J Environ Res Public Health 17(7):2309 Available from: https://www.mdpi.com/1660-4601/17/7/2309

3. World Health Organization (2020) COVID-19 weekly epidemiological update Available from: https:/www.who.int/docs/default-source/coronaviruse/situa tion-reports/20201012-weekly-epi-update-9.pdf 
4. Jeyanathan M, Afkhami S, Smaill F, Miller MS, Lichty BD, Xing Z (2020) Immunological considerations for COVID-19 vaccine strategies. Nat Rev Immunol 20(October):615-632. https://doi.org/10.1038/s41577-020-00434-6

5. Lurie N, Saville M, Hatchett R, Halton J (2020) Developing Covid-19 vaccines at pandemic speed. N Engl J Med 382(21):1969-1973. https://doi.org/10.1 056/NEJMp2005630

6. Glass CK, Ogawa S (2006) Combinatorial roles of nuclear receptors in inflammation and immunity. Nat Rev Immunol 6(1):44-55Available from: http://www.nature.com/articles/nri1748. https://doi.org/10.1038/nri1748

7. Liao M, Liu Y, Yuan J, Wen Y, Xu G, Zhao J, Cheng L, Li J, Wang X, Wang F, Liu L, Amit I, Zhang S, Zhang Z (2020) Single-cell landscape of bronchoalveolar immune cells in patients with COVID-19. Nat Med 26(6): 842-844Available from:. https://doi.org/10.1038/s41591-020-0901-9

8. Yuan B, Liu HQ, Yang ZR, Chen YX, Liu ZY, Zhang K, Wang C, Li WX, An YW, Wang JC, Song S (2020) Recurrence of positive SARS-CoV-2 viral RNA in recovered COVID-19 patients during medical isolation observation. Sci Rep 10(1):1-7. https://doi.org/10.1038/s41598-020-68782-w

9. Z Zheng J, Zhou R, Chen F, Tang G, Wu K, Li F, Liu H, Lu J, Zhou J, Yang Z, Yuan Y, Lei C, Wu X (2020) Incidence, clinical course and risk factor for recurrent PCR positivity in discharged COVID-19 patients in Guangzhou, China: a prospective cohort study. Henao-Martínez AF, editor. PLoS Negl Trop Dis 14(8):e0008648. https://doi.org/10.1371/journal.pntd.0008648

10. Gidari A, Nofri M, Saccarelli L, Bastianelli S, Sabbatini S, Bozza S, Camilloni B, Fusco-Moffa I, Monari C, De Robertis E, Mencacci A, Francisci D (2020) Is recurrence possible in coronavirus disease 2019 (COVID-19)? Case series and systematic review of literature. Eur J Clin Microbiol Infect Dis. https://doi. org/10.1007/s10096-020-04057-6

11. Lumley SF, O'Donnell D, Stoesser NE, Matthews PC, Howarth A, Hatch SB, Marsden BD, Cox S, James T, Warren F, Peck LJ, Ritter TG, de Toledo Z, Warren L, Axten D, Cornall RJ, Jones EY, Stuart DI, Screaton G, Ebner D, Hoosdally S, Chand M, Crook DW, O'Donnell A-M, Conlon CP, Pouwels KB, Walker AS, TEA P, Hopkins S, Walker TM, Jeffery K, Eyre DW (2020) Antibody status and incidence of SARS-CoV-2 infection in health care workers. N Engl J Med NEJMoa2034545 Available from: http://www.nejm.org/doi/10.1056/ NEJMoa2034545

12. Ramon S, Bancos S, Thatcher TH, Murant TI, Moshkani S, Sahler JM, Bottaro A, Sime PJ, Phipps RP (2012) Peroxisome proliferator-activated receptor $\gamma$ B cell-specific-deficient mice have an impaired antibody response. J Immunol 189(10):4740-4747 Available from: http://www.jimmunol.org/lookup/doi/1 0.4049/jimmunol.1200956

13. Garcia-Bates TM, Baglole CJ, Bernard MP, Murant TI, Simpson-Haidaris PJ, Phipps RP (2009) Peroxisome proliferator-activated receptor $\gamma$ ligands enhance human B cell antibody production and differentiation. J Immuno 183(11):6903-6912 Available from: http://www.jimmunol.org/lookup/doi/1 0.4049/jimmunol.0900324

14. Hughes TS, Giri PK, de Vera IMS, Marciano DP, Kuruvilla DS, Shin Y, Blayo A L, Kamenecka TM, Burris TP, Griffin PR, Kojetin DJ (2014) An alternate binding site for PPARy ligands. Nat Commun 5(1):3571 Available from: http://www.nature.com/articles/ncomms4571

15. Lee S, Nguyen MT (2015) Recent advances of vaccine adjuvants for infectious diseases. Immune Netw 15(2):51 Available from: https:// immunenetwork.org/DOlx.php?id=10.4110/in.2015.15.2.51

16. Chiron D, Bekeredjian-Ding I, Pellat-Deceunynck C, Bataille R, Jego G (2008) Toll-like receptors: lessons to learn from normal and malignant human B cells. Blood. 112(6):2205-2213. https://doi.org/10.1182/blood-2 008-02-140673

17. Chung JB, Silverman M, Monroe JG (2003) Transitional B cells: step by step towards immune competence. Trends Immunol 24(6):343-349. https://doi. org/10.1016/s1471-4906(03)00119-4

18. Jacob J, Kelsoe G, Rajewsky K, Weiss U (1991) Intraclonal generation of antibody mutants in germinal centres. Nature. 354(6352):389-392. https:// doi.org/10.1038/354389a0

19. Kelsoe G (1996) Life and death in germinal centers (redux). Immunity. 4(2): 107-111. https://doi.org/10.1016/S1074-7613(00)80675-5

20. Klein U, Dalla-Favera R (2008) Germinal centres: role in B-cell physiology and malignancy. Nat Rev Immunol 8(1):22-33. https://doi.org/10.1038/nri2217

21. Lightman SM, Utley A, Lee KP (2019) Survival of long-lived plasma cells (LLPC): piecing together the puzzle. Front Immunol 10(MAY):1-12

22. Kale J, Osterlund EJ, Andrews DW (2018) BCL-2 family proteins: changing partners in the dance towards death. Cell Death Differ 25(1):65-80Available from: http://wnw. nature.com/articles/cdd2017186. https:/doi.org/10.1038/cdd.2017.186
23. Wu J-S, Lin T-N, Wu KK (2009) Rosiglitazone and PPAR- $\gamma$ overexpression protect mitochondrial membrane potential and prevent apoptosis by upregulating anti-apoptotic Bcl-2 family proteins. J Cell Physiol 220(1):58-71. https://doi.org/10.1002/jcp.21730

24. Shashni B, Sakharkar KR, Nagasaki Y, Sakharkar MK (2013) Glycolytic enzymes PGK1 and PKM2 as novel transcriptional targets of PPARy in breast cancer pathophysiology. J Drug Target 21(2):161-174 Available from: http://www.ta ndfonline.com/doi/full/10.3109/1061186X.2012.736998

25. Wang W, Zhu Z, Zhu B, Ma Z (2011) Peroxisome proliferator-activated receptor- $\gamma$ agonist induces regulatory $T$ cells in a murine model of allergic rhinitis. Otolaryngol Neck Surg 144(4):506-513 Available from: http://journa Is.sagepub.com/doi/10.1177/0194599810396133

26. Szatmari I, Gogolak P, Im JS, Dezso B, Rajnavolgyi E, Nagy L (2004) Activation of PPARY specifies a dendritic cell subtype capable of enhanced induction of iNKT cell expansion. Immunity. 21(1):95-106Available from: https://inkinghub.elsevier.com/retrieve/pii/S1074761304001645. https://doi. org/10.1016/j.immuni.2004.06.003

27. Good-Jacobson KL, Tarlinton DM (2012) Multiple routes to B-cell memory. Int Immunol 24(7):403-408 Available from: https://academic.oup.com/ intimm/article-lookup/doi/10.1093/intimm/dxs050

28. Buckley CD, Gilroy DW, Serhan CN (2014) Proresolving lipid mediators and mechanisms in the resolution of acute inflammation. Immunity 40(3):315327Available from: https://linkinghub.elsevier.com/retrieve/pii/S1074761314 000776. https://doi.org/10.1016/j.immuni.2014.02.009

29. Carsetti R, Tozzi AE (2009) The role of memory B cells in immunity after vaccination. Paediatr Child Health (Oxford) 19:S160-S162. https://doi.org/1 0.1016/j.paed.2009.08.012

30. Kye Y-C, Park S-M, Shim B-S, Firdous J, Kim G, Kim HW, Ju Y-J, Kim CG, Cho C-S, Kim DW, Cho JH, Song MK, Han SH, Yun C-H (2019) Intranasal immunization with pneumococcal surface protein a in the presence of nanoparticle forming polysorbitol transporter adjuvant induces protective immunity against the Streptococcus pneumoniae infection. Acta Biomater 90:362-372. https://doi.org/10.1016/j.actbio.2019.03.049

31. Daynes RA, Jones DC (2002) Emerging roles of PPARs in inflammation and immunity. Nat Rev Immunol 2(10):748-759. https://doi.org/10.103 8/nri912

32. Cui Y, Miyoshi K, Claudio E, Siebenlist UK, Gonzalez FJ, Flaws J, Wagner KU, Hennighausen $L$ (2002) Loss of the peroxisome proliferation-activated receptor gamma (PPARY) does not affect mammary development and propensity for tumor formation but leads to reduced fertility. J Biol Chem 277(20):17830-17835. https://doi.org/10.1074/jbc.M200186200

33. Aldridge JR, Moseley CE, Boltz DA, Negovetich NJ, Reynolds C, Franks J, Brown SA, Doherty PC, Webster RG, Thomas PG (2009) TNF/iNOS-producing dendritic cells are the necessary evil of lethal influenza virus infection. Proc Natl Acad Sci U S A 106(13):5306-5311. https://doi.org/10.1073/pnas.0900655106

34. Moseley CE, Webster RG, Aldridge JR (2010) Peroxisome proliferatoractivated receptor and AMP-activated protein kinase agonists protect against lethal influenza virus challenge in mice. Influenza Other Respir Viruses 4(5):307-311. https://doi.org/10.1111/j.1750-2659.2010.00155.x

35. Cui H, Xie N, Banerjee S, Ge J, Guo S, Liu G (2019) Impairment of fatty acid oxidation in alveolar epithelial cells mediates acute lung injury. Am J Respir Cell Mol Biol 60(2):167-178. https://doi.org/10.1165/rcmb.2018-01520C

36. Delayre-Orthez C, Becker J, Guenon I, Lagente V, Auwerx J, Frossard N, Pons F (2005) PPARa downregulates airway inflammation induced by lipopolysaccharide in the mouse. Respir Res 6:1-10

37. Graham JB, Da Costa A, Lund JM (2014) Regulatory T cells shape the resident memory $T$ cell response to virus infection in the tissues. J Immunol 192(2):683-690. https://doi.org/10.4049/jimmunol.1202153

38. Lalor SJ, McLoughlin RM (2016) Memory $\gamma \delta$ T cells-newly appreciated protagonists in infection and immunity. Trends Immunol 37(10):690-702. https://doi.org/10.1016/j.it.2016.07.006

39. Mothe-Satney I, Murdaca J, Sibille B, Rousseau AS, Squillace R, Le Menn G, Rekima A, Larbret F, Pelé J, Verhasselt V, Grimaldi PA, Neels JG (2016) A role for peroxisome proliferator-activated receptor beta in T cell development. Sci Rep 6(September):1-12

40. Bishop-Bailey D (2004) FXR as a novel therapeutic target for vascular disease

41. Lochner M, Berod L, Sparwasser T (2015) Fatty acid metabolism in the regulation of T cell function. Trends Immunol 36(2):81-91. https://doi.org/1 0.1016/j.it.2014.12.005

42. Sullivan DO, Van Der Windt GJW, Huang SC, Jonathan D, Chang C, Buck MD, Qiu J, Smith AM, Lam WY, Diplato LM, Hsu F, Birnbaum MJ, Pearce EJ, 
Erika L (2014) Memory CD8+ T cells use cell intrinsic lipolysis. Immunity. 41(1):75-88. https://doi.org/10.1016/j.immuni.2014.06.005

43. Le Menn G, Neels JG (2018) Regulation of immune cell function by PPARs and the connection with metabolic and neurodegenerative diseases. Int J Mol Sci 19(6):1575. https://doi.org/10.3390/ijms19061575

44. Wenglong L, Zheng M, Ruiliang X, Pengjun Z (1996) Preliminary study on the reasons for coal mine-wall damage in Xuzhou-Huaibei area. Earthq Eng Eng Vib 16(4):127-133

45. Aksoylar HI, Tijaro-Ovalle NM, Boussiotis VA, Patsoukis N (2020) T cell metabolism in cancer immunotherapy. Immunometabolism 2(3):e200020. https://doi.org/10.20900/immunometab20200020

46. Nobs SP, Kopf M (2018) PPAR-y in innate and adaptive lung immunity. J Leukoc Biol 104(4):737-741. https://doi.org/10.1002/JLB.3MR0118-034R

47. Pan Y, Tian T, Park CO, Lofftus SY, Mei S, Liu X, Luo C, O'Malley JT, Gehad A, Teague JE, Divito SJ, Fuhlbrigge R, Puigserver P, Krueger JG, Hotamisligil GS, Clark RA, Kupper TS (2017) Survival of tissue-resident memory T cells requires exogenous lipid uptake and metabolism. Nature. 543(7644):252256. https://doi.org/10.1038/nature21379

48. Chuah J (2020) P iii M. Statut Conv Priv Int Law 4:325-325

49. Chamoto K, Chowdhury PS, Kumar A, Sonomura K, Matsuda F, Fagarasan S, Honjo T (2017) Mitochondrial activation chemicals synergize with surface receptor PD-1 blockade for T cell-dependent antitumor activity. Proc Natl Acad Sci U S A 114(5):E761-E770. https://doi.org/10.1073/pnas.1620433114

50. Chowdhury PS, Chamoto K, Kumar A, Honjo T (2018) PPAR-induced fatty acid oxidation in $T$ cells increases the number of tumor-reactive $C D 8+T$ cells and facilitates anti-PD-1 therapy. Cancer Immunol Res 6(11):13751387. https://doi.org/10.1158/2326-6066.CIR-18-0095

51. Balmer ML, Ma EH, Bantug GR, Grählert J, Pfister S, Glatter T, Jauch A, Dimeloe S, Slack E, Dehio P, Krzyzaniak MA, King CG, Burgener AV, Fischer M, Develioglu L, Belle R, Recher M, Bonilla WW, Macpherson AJ, Hapfelmeier $\mathrm{S}$, Jones RG, Hess C (2016) Memory CD8+ T cells require increased concentrations of acetate induced by stress for optimal function. Immunity. 44(6):1312-1324. https://doi.org/10.1016/j.immuni.2016.03.016

52. Patsoukis N, Bardhan K, Chatterjee P, Sari D, Liu B, Bell LN, Karoly ED, Freeman GJ, Petkova V, Seth P, Li L, Boussiotis VA (2015) PD-1 alters T-cell metabolic reprogramming by inhibiting glycolysis and promoting lipolysis and fatty acid oxidation. Nat Commun 6:1-13

53. Masopust D, Kaech SM, Wherry EJ, Ahmed R (2004) The role of programming in memory T-cell development. Curr Opin Immunol 16(2): 217-225. https://doi.org/10.1016/j.coi.2004.02.005

54. Channappanavar R, Twardy BS, Suvas S (2012) Blocking of PDL-1 interaction enhances primary and secondary CD8 $t$ cell response to herpes simplex virus-1 infection. PLoS One 7(7):e39757. https://doi.org/10.1371/journal.pone. 0039757

55. Johnson RMG, Dong H (2017) Functional expression of programmed deathligand 1 (B7-H1) by immune cells and tumor cells. Front Immunol 8(AUG): $1-9$

\section{Publisher's Note}

Springer Nature remains neutral with regard to jurisdictional claims in published maps and institutional affiliations.

\section{Submit your manuscript to a SpringerOpen ${ }^{\circ}$ journal and benefit from:}

- Convenient online submission

- Rigorous peer review

- Open access: articles freely available online

- High visibility within the field

- Retaining the copyright to your article

Submit your next manuscript at $\boldsymbol{\nabla}$ springeropen.com 